\title{
Satisfaction and usability of an information and communictions technology in nursing education: a pilot study
}

Satisfação e usabilidade de uma tecnologia de informação e comunicação no ensino de enfermagem: um estudo piloto

Satisfacción y usabilidad de una tecnología de la información y la comunicación en la formación de enfermería: un estudio piloto

Inês Silva*iD; Joana Ângelo**iD; Francisco Santos***iD; Maria José Lumini***(iD; Teresa Martins***** (D)

\begin{abstract}
Background: The literature suggests that interactive educational tools can improve the teaching-learning process. Objective: To evaluate the usability and satisfaction capability of a technological platform, designed for nursing students, used as a support tool to learn the procedures related to patient positioning.

Methodology: A study with 2 cross-reference evaluation moments was conducted. One hundred and twenty-two students enrolled in the $1^{\text {st }}$ semester curricular unit of the Undergraduate Degree in Nursing, answered a questionnaire, for the assessment of the satisfaction level regarding the currently used model (with no access to the platform). Seventy-eight students enrolled in the second semester had access to the educational platform and gave their opinion on the efficacy, relevance, and responsiveness of the platform.

Results: The students considered the tool useful. The overall evaluation had a mean of 8.01 (on a 0-10 scale).

Conclusion: The correct use of the virtual learning object proves to be useful for the teaching-learning process, contributing to better learning and indirectly to the excellence of nursing care.
\end{abstract}

Keywords: nursing; education; technology

\section{Resumo}

Enquadramento: A literatura sugere que as ferramentas educacionais interativas podem constituir uma mais-valia para o processo de ensino-aprendizagem.

Objetivo: Avaliar a usabilidade e a satisfação de uma plataforma tecnológica, destinada a estudantes de enfermagem, usando como objeto de apoio à aprendizagem, procedimentos relativos ao posicionar pessoa.

Metodologia: Desenvolveu-se um estudo com 2 momentos de avaliaçáo de referência cruzada. Cento e vinte e dois estudantes, inscritos numa unidade curricular no primeiro semestre do curso de licenciatura em enfermagem responderam a um questionário, para apurar a satisfação face ao modelo em uso (sem recurso à plataforma). Setenta e oito estudantes inscritos no segundo semestre tiveram acesso à plataforma educativa e deram a sua opinião quanto à eficácia, pertinência e responsividade da plataforma.

Resultados: A ferramenta foi considerada útil, obtendo uma avaliação média de 8,01 (em 10).

Conclusáo: $\mathrm{O}$ uso correto de um objeto virtual de apoio à aprendizagem mostra facilitar o processo de ensino-aprendizagem, contribuindo para uma melhor aprendizagem e indiretamente para a excelência dos cuidados de enfermagem.

Palavras-chave: enfermagem; educação; tecnologia

*MSc., RN, ESEP, 4200-072 Porto, Portugal [inescosta.silva@sapo.pt]. Dhttps://orcid.org/00000003-3787-8629. Contribution to the article: bibliographic review of the topic, empirical work, writing of the manuscript. Address for correspondence: Rua D. Nuno Alvares Pereira, 267; 4760-480, Famalicão, Portugal.

**MSc., RN, ESEP, 4420-072 Porto, Portugal [joana_angelo@hotmail.com]. (1) https:/ orcid.org/0000-0003-3219-9870. Contribution to the article: study conception and design, revision of the manuscript.

***BSc., Computer Engineer, ISEP, 4200-072 Porto, Portugal [francisco.m.santos@icloud. com]. (D) https://orcid.org/0000-0002-0290-3102. Contribution to the article: empirical work ****:Ph.D., Adjunct Professor, ESEP, 4200-072 Porto, Portugal [lumini@esenf.pt]. O https:/ orcid.org/0000-0002-2951-8001. Contribution to the article: study conception and design, and revision of the manuscript.

*****:Ph.D., Coordinating Professor, ESEP, 4200-072 Porto, Portugal [teresam@esenf.pt]. (D https://orcid.org/0000-0003-3395-7653. Contribution to the article: study conception and design, writing and revision of the manuscript.

Marco contextual: La literatura sugiere que las herramientas educativas interactivas pueden constituir un beneficio para el proceso de enseñanza-aprendizaje.

Objetivo: Evaluar la usabilidad y satisfacción de una plataforma tecnológica, dirigida a estudiantes de enfermería, para lo cual se utilizaron, como objeto de apoyo al aprendizaje, procedimientos relacionados con el posicionamiento de la persona.

Metodología: Se desarrolló un estudio con 2 momentos de evaluación de referencias cruzadas. Ciento veintidós estudiantes matriculados en una unidad curricular en el primer semestre del Grado de Enfermería respondieron a un cuestionario para evaluar su satisfacción en relación con el modelo en uso (sin utilizar la plataforma). Setenta y ocho estudiantes matriculados en el segundo semestre tuvieron acceso a la plataforma educativa y dieron su opinión sobre la efectividad, relevancia, pertinencia y la respuesta de la plataforma.

Resultados: La herramienta se consideró útil, y obtuvo una evaluación media de 8,01 (sobre 10).

Conclusión: El uso correcto de un objeto de apoyo al aprendizaje virtual facilita el proceso de enseńanza-aprendizaje, lo que contribuye a un mejor aprendizaje e indirectamente a la excelencia en la atención de enfermería.

Palabras clave: enfermería; educación; tecnología 


\section{Introduction}

The evolution of scientific and technological knowledge implies several social modifications and transformations, namely the change of the educational paradigm. In this respect, one issue that must be taken into account is the integration of Information and Communications Technologies (ICT) in the teaching-learning process in nursing.

The use of educational technologies, including ICT, improves the teaching-learning process because of their interactivity, the possibility of integrating different resources, and their easy adaptation to multiple learning styles (Struchiner \& Ricciardi, 2003).

The most relevant interactive tools are virtual learning environments and objects. Virtual learning environments are technological resources available in cyberspace and capable of promoting the teaching-learning process (Zancanaro, Santos, \& Todesco, 2011). A virtual learning object is any digital material that can be reused for teaching support (Wiley, 2000). These tools allow students to access relevant information flexibly after the teaching and instruction given by teachers, thus promoting their study according to their learning needs. The use of new technologies is fundamental in daily nursing teaching, so it is important to know if using these new resources improves the teaching-learning process and if they are designed according to the profile of their users.

The present study aims to assess the usability and satisfaction of a technological platform, currently at use in a nursing school, which provides a set of nursing procedures for support to a curricular unit. This study specifically aims to evaluate a new topic related to the procedure, introduced in this platform, that is, a therapeutic action performed by the nurse, namely patient positioning.

\section{Background}

The internet and the virtual learning objects and environments are some of the digital resources that can be used in the teaching-learning process of future nursing professionals, making it more flexible, dynamic, interactive, and creative. Thus, students become more active, autonomous, and responsible participants.
Consequently, new teaching approaches are necessary to promote this process, based on digital educational technologies that correspond to "all products with the technical-scientific approach, with greater or lesser potential for interaction, to be used in computers, tablets, or smartphones" (Fonseca et al., 2015, p. 142).

This new communicational approach in teaching was possible primarily because of the inclusion of ICT in education since they relate to the "procedures, methods, and equipment of information treatment and communication" (Ramos, 2008, p. 5). The education area gained alternative tools that can improve the teaching-learning process. The technologies stimulate the autonomy and involvement of students, as they feel encouraged to establish an exchange of information and knowledge between peers and between themselves and the teacher (Kim, Park, \& Shin, 2016). The students, then, become the main responsible person for the construction of their knowledge and will play a more active role in seeking solutions for their learning needs (Roney, Westrick, Acri, Aronson, \& Rebeschi, 2017).

A virtual learning object must be flexible, simple, easily upgradeable, and interoperable and facilitate its reuse without maintenance costs (Ministério da Educação, 2007).

The successful use of educational technologies in the teaching-learning process depends on a good planning, their design, and a user-centered pedagogical content conception, meaning it is crucial to know the intended target audience (Lumini, 2015).

Since it is a central topic in nursing, it is essential to understand if using these new technological resources can or cannot improve the teaching-learning process of students as future professionals. The Nursing Procedure Platform (known by the acronym PoPE) was designed to support the Undergraduate Degree in Nursing (CLE), particularly in learning nursing procedures and techniques.

During the CLE, students learn more than 200 different procedures and techniques. A phased evolution was decided, and the first step was to develop just the contents of one curricular unit. Thus, the chosen curricular unit was of the $2^{\text {nd }}$ year undergraduate degree in nursing, with laboratory practice classes where students perform procedures in simulation situations involving bathing, dressing, and undressing, 
assisting in walking, positioning and transferring the person with self-care impairment.

The platform was based on the ADDIE Model (Filatro, 2004). Its design began with a diagnosis phase in order to understand the problem and find workable solutions. Then, the design and development phase defined the learning objectives, contents, strategies, used tools, and the navigation structure. The platform was under analysis during its conception and experimental phase (Ângelo, 2017). The platform was designed to integrate procedures with pictures and videos with human narration, hyperlinks to other procedures, and tests for students to assess their knowledge. The questions of the test are generated randomly from a bank. After finishing a test, the student receives the results and can access the corrected test. As there were multiple resources to be integrated into the platform, it was decided that the trial phase would only focus on nursing procedures related to patient transfer because each new tool upgrade would require the partial evaluation of integrated functions and contents.

The platform is compatible with Android, iPhone/iPod Touch, iPad, Windows Phone 7, and BlackBerry operating systems. It was built through an open-source solution, with open-source code that provides and shares functionalities in a set of attachments for webpage presentation. The digital solution used (WordPress) offers a system of templates that allows the user to rearrange the layout using widgets without editing the source code and also to install and switch themes. The PHP and HTML codes of the themes can also be edited to add customized functionalities. The versatility of the platform allows creating customized solutions while keeping an interface with a qualified and professional look. WordPress requires basic programming and web design skills, yet its use is very intuitive, meaning a more affordable creation, maintenance, and functioning of an electronic platform (www.wordpress. com). The platform is available at http://pope. esenf.pt/wordpress.

\section{Research Questions}

Did students who used the electronic platform with patient positioning nursing procedures manifest a greater satisfaction with the leaning method than students who used the traditional method (studying with paper-based material)?

How do students measure the platform's usability?

\section{Methodology}

To assess the usability and satisfaction of the platform with an added new theme, patient positioning, a study was developed using a quantitative approach, with two moments of cross-reference evaluation. Both semesters of the same academic year have this curricular unit. The institution's study plan works in a mirror format, meaning half of the students enroll in a set of curricular units for the first semester and will switch with the other half for the second, enrolling in the units the other half attended in the first semester. The first sample included first semester students enrolled in the curricular unit who had no access to the contents regarding patient positioning on the platform. The second sample included second-semester students enrolled in the same curricular unit who had access to the contents of the patient positioning procedure on the platform. The sampling method was nonprobabilistic by convenience, both samples corresponding to students enrolled in the curricular unit who voluntarily accepted the invitation to answer to an online questionnaire. The cross-over layout was chosen for these samples, as the assumption is that the first semester students enrolled in the curricular unit do not differ, as to their profile, from the second half students who enrolled in the same curricular unit. The satisfaction level of the first sample group $(n=$ 122) was assessed regarding the used model (with no access to the platform), and the participants were asked if the procedures on an interactive platform would be considered an advantage for the teaching-learning process, and which features should be included in the electronic tool. The second sample group $(n=78)$ was enquired about their level of satisfaction with the platform and its effectiveness, relevance, and responsiveness relating to the added contents about the procedures under analysis.

For information analysis, the IBM SPSS Statistics software, version 24.0 for Windows, was used. It was used descriptive and inferential statistical analysis, using the $t$-test for independent samples. The study was approved by the Technical-Scientific Council and the Ethics Committee of the 
higher education institution, respecting all the ethical and legal issues inherent to the research processes (ESEP, registration code no. 2017/122). The participants in the study were duly informed of the objectives, path, and nature of the (possible) research results, as well as the guarantee for data confidentiality. All students who participated in the research were free to give up without or penalty.

\section{Results}

The first moment of evaluation included 122 students, with a mean age of 20.38 years $(S D=$
3.87), ranging between 18 and 41, the majority being female $(89.3 \%)$. Students reported the regular use of some technological means, namely the internet, to study the subject matter of the analyzed curricular unit. They expressed an average satisfaction of $8.27(S D=1.72)$, on a scale of 0 to 10 , with the used system to access the nursing procedure relating to patient positioning available on the software system used by the school for the production and management of educational activities (moodle) in PDF format (Table 1). The students' opinion when asked if they would consider useful adding these procedures to the PoPE was evident.

Table 1

Student satisfaction about Patient Positioning nursing procedures available in Moodle (before the addition of these contents to PoPE)

\begin{tabular}{|c|c|c|c|}
\hline Items & Mean $(S D)$ & Minimum & Maximum \\
\hline $\begin{array}{l}\text { Are you satisfied with the current presentation format for the } \\
\text { Patient Positioning nursing procedure (pdf format)? }\end{array}$ & $8.27(1.72)$ & 3 & 10 \\
\hline $\begin{array}{l}\text { Do you consider the technical language used in the patient } \\
\text { positioning procedure understandable and clear? }\end{array}$ & $7.96(1.63)$ & 2 & 10 \\
\hline $\begin{array}{l}\text { Do you consider the images presented in the pdf document of the } \\
\text { procedure understandable and clarifying? }\end{array}$ & $7.91(1.85)$ & 1 & 10 \\
\hline $\begin{array}{l}\text { How useful do you consider adding the Patient Positioning nursing } \\
\text { procedure to PoPE? }\end{array}$ & $9.16(1.32)$ & 4 & 10 \\
\hline
\end{tabular}

Note. $S D=$ standard deviation; PoPE = Platform of Nursing Procedures.

Many students stated, in free-text, they would like that all nursing procedures with practical laboratory classes should be integrated into PoPE. Regarding the platform's structure, they namely suggested aspects about the operational capability of the platform and its organization, as well as the creation of a forum to allow the communication between students and teachers. The second evaluation moment, after integrating the patient positioning nursing procedure, included 78 students, with a mean age of 20.21 years $(S D=3.28)$, the minimum age being 19 and the maximum 32 . The majority, also female $(88.5 \%)$, reported having spent less than an hour on the platform $(76.9 \%)$ to prepare for the laboratory classes. $83.3 \%$ of the sample $(N=65)$ used a computer to access the PoPE, $11.5 \%(N=9)$ accessed through mobile phone and, finally, $5.1 \%(N=4)$ used a tablet. To assess the general reaction after the use of the interactive tool (with a $0-10$ scale), the parameters in Table 2 were measured.

Overall, the students consider the tool very useful and appropriate. They rated "language clarity," "video relevance," and "image relevance" as the best features, and "graphic presentation" as the worst. The parameters "language clarity," "interactivity," "video quality" and "image quality" obtained the lowest minimum score, ranging between three and four. 
Table 2

Group 2 - general user reaction

\begin{tabular}{llcc}
\hline Items & Mean $(S D)$ & Minimum & Maximum \\
\hline Graphic presentation & $7.28(1.32)$ & 5 & 10 \\
User friendliness & $7.95(1.31)$ & 5 & 10 \\
Language clarity & $8.06(1.37)$ & 4 & 10 \\
Interactivity & $7.44(1.56)$ & 3 & 10 \\
Video relevance & $8.36(1.32)$ & 5 & 10 \\
Video quality & $7.79(1.38)$ & 4 & 10 \\
Image relevance & $8.08(1.26)$ & 5 & 10 \\
Image quality & $7.76(1.36)$ & 4 & 10 \\
Audio relevance & $7.86(1.34)$ & 5 & 10 \\
Audio quality & $7.71(1.31)$ & 5 & 10 \\
Overall assessment of the tool & $8.01(1.19)$ & 5 & \\
\hline
\end{tabular}

Note. $S D=$ Standard deviation.

Nearly all the participants $(98.7 \% ; N=77)$ answered yes to the question "Do you consider that the inclusion of "patient positioning" nursing procedures in PoPE facilitated the teaching/ learning process?”.

Figure 1 summarizes the dispersion of ratings attributed to the 11 analyzed parameters. The presence of outliers is evident in items such as "graphic presentation," "interactivity," "audio quality," and "overall assessment of the tool."
They can be interpreted as more demanding or facilitating opinions about the usefulness and functionality of the virtual learning object. The overall assessment of the tool, regarding the analyzed procedures, is very good since the box plot shows no upper whisker, meaning that two-thirds of the participants rated between 7 and 10. "Video relevance" was the item with the highest score and valorization.

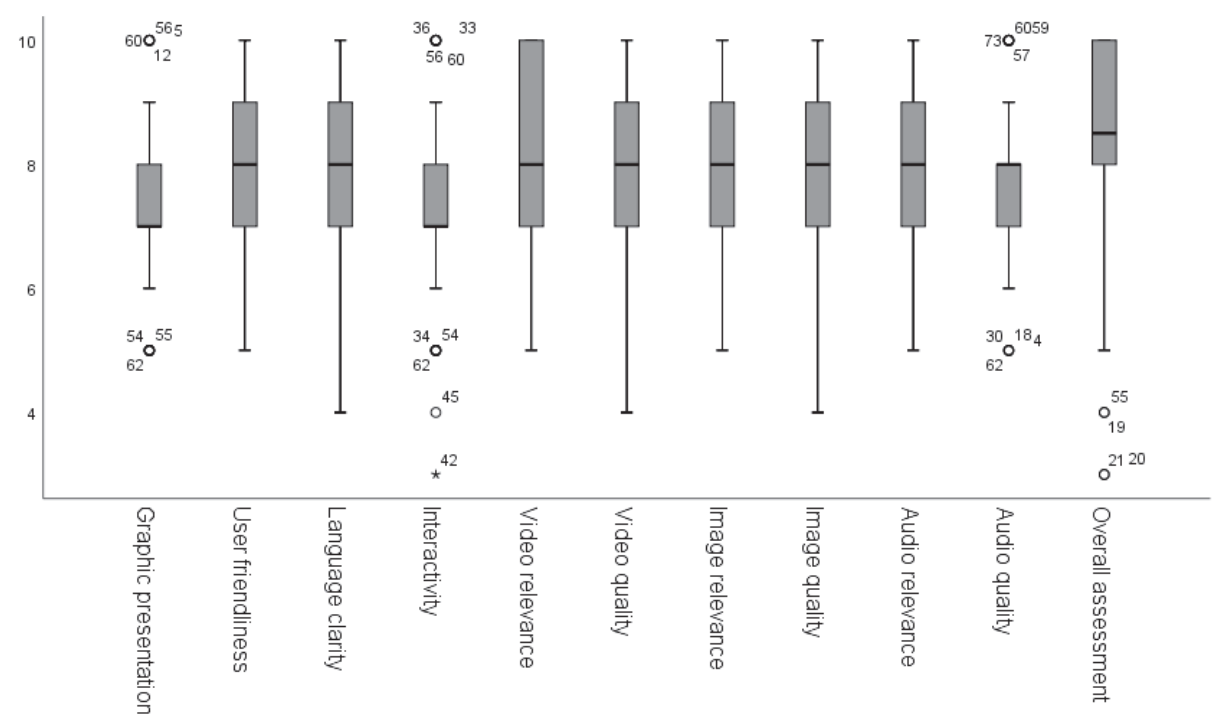

Figure 1. Evaluation of the electronic tool. 
The $t$-test for independent samples showed no statistical differences between the satisfaction level of $1^{\text {st }}$-semester students and $2^{\text {nd }}$-semester students regarding procedure presentation.

\section{Discussion}

The PoPE platform was designed and developed as a complementary tool for the teaching-learning process and not as a class substitute. This free-access, anonymous, and free-of-charge platform was the object of a preliminary study and is currently being implemented in a nursing school (Ângelo, 2017).

Several studies have revealed benefits for the teaching-learning process, mainly the use of ICT, including virtual learning objects (Aredes, Góes, Silva, Gonçalves, \& Fonseca, 2015; Kim et al., 2017; Tamashiro \& Peres, 2014), that adapt to and respect the pace of every student (Rawson \& Quinlan, 2002; Roney et al., 2017). Aredes et al. (2015) add that resources allow respected the learning rhytm of each student and contribute to imprve his or her autonomy enhancement.

Digital technology can improve the learning process and motivation of students in this process (Reynolds, Harper, Mason, Cox, \& Eaton, 2008), as well as their attitude which, according to Buzzell, Chamberlain, and Pintauro (2002), is more responsive to multimedia. In their integrative review, Silveira and Cogo (2017) provide us with a wide variety of technologies used in nursing education, which improve the acquisition of theoretical frameworks and support practices. A limitation of the adoption of such resources is the cost of its acquisition or development, meaning that many institutions cannot access them (Silveira \& Cogo, 2017).

The present study aimed to assess the usability and satisfaction of PoPE, in what concerns the integration of the patient positioning nursing procedures.

The first evaluation moment showed that students use several types of equipment to access the internet, meaning computers, although still the most used, are no longer the only access means. Students increasingly rely on other devices such as smartphones and tablets. This diagnostic information was essential for the development of the virtual learning object.
The level of student satisfaction with the procedures (PDF format) before their inclusion in PoPE, does not appear to be very different from the overall assessment after their inclusion on the platform. However, this comparison may lead to several biases. On the one hand, the participants are not the same, although they are comparable in our opinion. On the other hand, the fact that they were questioned in different contexts may explain the results. In fact, for the evaluation of the PoPE functioning with the patient positioning procedures content, students were previously questioned regarding a broad set of items ("graphic presentation", "user friendliness", "language clarity", "interactivity," "relevance" and "video, image, and audio quality") that leads to a more detailed and specific assessment, meaning a more rigorous attitude. The authors believe that, if the same students had expressed their opinion, the results would have been different. However, the authors also believe that, from the moment that the students had completed the curricular unit, they would not be motivated or interested in evaluating the functionality and relevance of the virtual object with these procedures.

Perhaps including the question about whether the integration of procedures in PoPE had contributed to the learning process would have been a more reliable strategy.

It seems evident that, concerning the use of PoPE, the interaction of different media, including photos, videos with human narration and a quiz to assess knowledge, as well as texts on the procedures, should be more appreciated than the simple procedures available only with pictures and itext. According to Reynolds et al. (2008), the use of dynamic images and videos can be a greater contribution when compared with pictures and texts. This interactive tool allows the user to navigate the program in a similar way to the natural learning process by interrelating the available information (Struchiner \& Ricciardi, 2003).

Regarding the functionality evaluation, the video relevance was the parameter most valued by students, with a mean score of 8.36 . These results show that this type of resources is important for the development of nursing practice skills. Also, image relevance and language clarity in video narration also stand out.

Besides the design of this educational techno- 
logy and its included resources, it was important to include tests that allow students to get feedback about what they learned. This idea is reinforced by Griffin (2003) and Reynolds et al. (2008). In this respect, a quiz was included in the PoPE, with randomly generated multiple-choice questions about the procedures related to patient positioning, so that students can test their knowledge, analyze the results, and check the correct/incorrect answers, as well as follow the instructions designed for more successful studying. It must be noted that the quiz allows the student to test knowledge informally, without committing to a formal assessment of the associated curricular unit. It is believed that repetition and feedback-based reinforcement because it is immediate, improves learning. Students suggested the inclusion of all nursing procedures with laboratory practice component in the platform, meaning they recognize their usefulness and effectiveness.

Therefore, the educational platforms can contribute significantly to the academic training process of nursing students, aiming at significant learning, which can lead, directly and indirectly, to the excellence of nursing care delivery.

\section{Conclusion}

Although the study had some limitations, mainly the use of the cross-reference sampling method and the fact that this assessment focuses only on the patient positioning procedures, the authors of this study believe that resorting to virtual learning objects can facilitate the development of skills. It is a matter of taking advantage of the current technological era where information, creativity, and collaboration are increasingly valuable.

The PoPE can be used as a study method, encouraging the acquisition of knowledge through visual memory stimulation and supporting communication between teachers and students. It can also be used as a complementary tool in classroom settings, thus increasing its dynamism and interactivity.

This study provides input for the future of nursing education because of its suitability to the current situation of ICT use in teaching and learning processes in higher education. The conduction of this study and the analysis of the national and international literature on this topic not only show that ICT can contribute significantly to the academic training process of nursing students, but also that there is an actual need to continue the investment in ICT at the university level and to produce further research to support this reality in the area of nursing in Portugal.

\section{References}

Ângelo, J. C. (2017). Desenvolvimento de uma plataforma informática destinada aos Estudantes do Curso de Licenciatura em Enfermagem: Estudo Piloto (Master's Dissertation). Retrieved from http://hdl.handle. net/10400.26/18941

Aredes, N., Góes, F. S., Silva, M. A., Gonçalves, M. F., \& Fonseca, L. M. (2015). Objeto digital em enfermagem neonatal: impacto na aprendizagem de estudantes. Revista Eletrónica de Enfermagem, 17(4), 1-11. Retrieved from https://www.fen.ufg.br/revista/ v17/n4/pdf/v17n4a10.pdf

Buzzell, P. R., Chamberlain, V. M., \& Pintauro, S. J. (2002). The effectiveness of web-based, multimedia tutorials for teaching methods of human body composition analysis. Advances in Physiology Education, 26(1), 21-29. doi:10.1152/ advan.00007.2001

Filatro, A. (2004). Design instrucional contextualizado: Educação e tecnologia. São Paulo, Brasil: Senac.

Fonseca, L. M., Tsai, M. L., Dias, D. M., Scochi, C. G., Fernandes, A. M., Martins, J. C., \& Rodrigues, M. A. (2015). Design emocional e as suas contribuiçóes para a tecnologia educacional digital na saúde e na enfermagem: Revisão integrativa. Revista de Enfermagem Referência, 4(6), 141-149. Retrieved from http:// www.redalyc.org/pdf/3882/388241612006_2.pdf

Griffin, J. D. (2003). Technology in the teaching of neuroscience: Enhanced student learning. Advances in Physiology Education, 27(3), 146-155. doi:10.1152/ advan.00059.2002

Kim, J., Park, J. H., \& Shin, S. (2016). Effectiveness of simulation-based nursing education depending on fidelity: a meta-analysis. BMC Medical Education, 16, 152. doi: 10.1186/s12909-016-0672-7

Lumini, M. (2015). Tecnologias educacionais interativas: Contributo para o desenvolvimento de conhecimentos dos familiares cuidadores (Ph.D Thesis). Retrieved from https://repositorio-aberto.up.pt/ handle/10216/82527? mode=full

Ministério da Educação. (2007). Objetos de aprendizagem: Uma proposta de recurso pedagógico. Brasília, Brasil: 
Secretaria de Educação à Distância. Retrieved from http://rived.mec.gov.br/artigos/livro.pdf

Ramos, S. (2008). Tecnologias da informação e comunicação: Conceitos básicos. Retrieved from https://www. passeidireto.com/arquivo/5789244/tic-conceitos_basicos_sr_out_2008

Rawson, R. E., \& Quinlan, K. M. (2002). Evaluation of a computer-based approach to teaching acid/base physiology. Advances in Physiology Education, 26(2), 85-97. doi:10.1152/ advan.00042.2001

Reynolds, P. A., Harper, J., Mason, R., Cox, M. J., \& Eaton, K. (2008). An intricate web - designing and authoring a web-based course. British Dental Journal, 204(9), 519-524. doi:10.1038/sj.bdj.2008.351

Roney, L., Westrick, S., Acri, M., Aronson, B., Rebeschi, L. (2017). Technology use and technological self-efficacy among undergraduate nursing faculty. Nursing Education Perspectives, 38(3), 113-118. doi:10.1097/01.NEP.0000000000000141

Silveira, M., \& Cogo, A. L. (2017). The contributions of digital technologies in the teaching of nursing skills: An integrative review. Revista Gaúcha de Enfermagem, 38(2), e66204. doi:10.1590/19831447.2017.02.66204

Struchiner, M., \& Ricciardi, R. (2003). Princípios, modelos e tecnologias de informação e comunicação em processos educativos das ciências biomédicas e da saúde. Revista Rio de Janeiro, 11, 56-63. Retrieved from http://www.forumrio.uerj.br/documentos/ revista_11/11-Struchiner.pdf

Tamashiro, L. M., \& Peres, H. H. (2014). Desenvolvimento e avaliaçáo de objetos de aprendizagem sobre administraçáo de medicamentos por via intramuscular. Revista Latino-Americana de Enfermagem, 22(5), 716-723. doi:10.1590/0104-1169.3647.2472

Wiley, D. (2000). The instructional use of learning objects. Retrieved from http://www.reusability.org/read/

Zancanaro, A., Santos, P., \& Todesco, J. (2011). Requisitos de um ambiente virtual de aprendizagem para TV digital interativa. Revista Novas Tecnologias na Educação, 9 (1), 1-11. Retrieved from http://seer. ufrgs.br/index.php/renote/article/view/21984/12752 